\title{
MIR26A2 Gene
}

National Cancer Institute

\section{Source}

National Cancer Institute. MIR26A2 Gene. NCI Thesaurus. Code C80745.

This gene is involved in the regulation of gene expression and plays a role in the development of hepatocellular and thyroid carcinomas as well as Burkitt lymphoma. 